JOURNAL OF TRACE ELEMENTS IN MEDICINE AND BIOLOGY (ISSN: 0946-672X) 28: (3) pp. 317-321. (2014)

DOI:10.1016/jtemb.2014.02.005

\title{
Cisplatin administration influences on toxic and non-essential element metabolism in rats
}

Klára Szentmihályi ${ }^{\mathrm{a}}$, Zoltán May ${ }^{\mathrm{a}}$, Gábor Szénási ${ }^{\mathrm{b}}$, Csaba Máthé $^{\mathrm{c}}$, Andor Sebestény ${ }^{\mathrm{d}}$, Mihály Albert ${ }^{\mathrm{e}}$, Anna Blázovics ${ }^{\mathrm{f}}$

${ }^{a 1}$ Institute of Materials and Environmental Chemistry, Research Centre for Natural Sciences of the HAS, H-1025 Budapest, Pusztaszeri út 59-67, Hungary; szentmihalyi.klara@ttk.mta.hu

${ }^{\mathrm{b}}$ Institute of Pathophysiology, Semmelweis University, H-1089 Budapest, Hungary;

szenasi.gabor@med.semmelweis-univ.hu

${ }^{c}$ Department of Pulmonology, Semmelweis University, H-1125 Budapest, Hungary; mathecs@pulm.sote.hu

${ }^{\mathrm{d}}$ Laboratory Animal Science Unit, Faculty of Veterinary Science, Szent István University, H-1078

Budapest, Hungary; andor.sebesteny@gmail.com

${ }^{\mathrm{e}}$ Vetmed Laboratory Ltd., H-1143 Budapest, Hungary; albert.mihaly@iif.hu

${ }^{\mathrm{f}}$ Department of Pharmacognosy, Semmelweis University, H-1085 Budapest, Hungary; blazovics.anna@pharma.semmelweis-univ.hu

\section{*Corresponding author: Dr. Klára Szentmihályi}

Institute of Materials and Environmental Chemistry, Research Centre for Natural Sciences of the HAS, H-1025 Budapest, Pusztaszeri út 59-67, Hungary; Tel: +36-1438-4141, Fax: +36-1438-1139, email: szentmihalyi.klara@ttk.mta.hu 


\title{
Running title: Cisplatin's effects on element metabolism
}

\begin{abstract}
Nowadays several papers deal with the effectiveness and side effects of metal complexes, especially cisplatin, in cancer therapy. The excretion of essential metal elements from the body is a serious problem in the treatment, but there are no data concerning the distribution and metabolism of toxic and nonessential elements. Therefore our aim was to study the concentration of some of these elements after treatment with cisplatin. Male Wistar rats $(n=20,175-190 \mathrm{~g})$ were randomly divided into 2 groups ( $\mathrm{n}=10 /$ group). The control group received $1 \%(\mathrm{w} / \mathrm{v})$ methyl cellulose at $10 \mathrm{~mL} / \mathrm{kg}$ body weight, p.o. by gastric gavage twice daily for 14 days, while cisplatin was injected i.p. in a single dose of $6.5 \mathrm{mg} / \mathrm{kg}$ body weight. Inductively coupled plasma optical emission spectrometry (ICP-OES) was used for measuring Al, B, Ba, Cr, Li, Ni, Pb, Pt, Sb, Si, Sn, Sr and V content in plasma, liver and kidney. Liver total scavenger capacity, diene conjugate content and malondialdehyde concentration were also determined. Cisplatin elevated the free radical reactions in the liver, although redox balance did not change significantly. According to the study it seems that the metabolism of $\mathrm{Al}, \mathrm{Ba}, \mathrm{Cr}, \mathrm{Ni}, \mathrm{Pb}$, $\mathrm{Sr}$ were changed by the effect of cisplatin, and the most notable alterations were found for $\mathrm{Al}$ and $\mathrm{Pb}$. Therefore, besides the toxic effect of and free radical induction by $\mathrm{Pt}$, the side effects of increased levels of other toxic and non-essential elements have to be taken into consideration.
\end{abstract}

Keywords: Cisplatin; Rats; Aluminum; Pro-oxidant effect; Toxic element 


\section{Introduction}

Cisplatin, oxaliplatin and carboplatin are known platinum derivatives, which are effective in the treatment of several tumors. Ciplatin (cis-diamminedichloroplatinum II, CDDP) is a widely used active anticancer agent in testicular, ovarian and bladder carcinomas, head and neck squamous cell carcinoma, and non-small cell lung cancers [1]. Its use in clinical practice is restricted because of its strong side effects affecting mainly the liver and kidney [2]. Platinum complexes are well-known DNA alkylating agents, and their interaction with proteins may be a part of a series of molecular events [3]. They can modulate signal transduction pathways and induce apoptotic responses. Platinum complexes induce the activation of members of the mitogen-activated protein kinase (MAPK) family [4]. Inhibition of the constitutively activated signal transducers and activators of transcription (STAT) in malignant cells may be one of the key molecular mechanisms for the antitumor effects of platinum complexes. Platinum compounds disrupt STAT3 signaling and suppress its biological functions. New platinum complexes (CPA-1, CPA-7, $\left.\mathrm{Pt}(\mathrm{IV}) \mathrm{Cl}_{4}\right)$ block STAT3 activity in vitro at low micromolar concentrations. Contrary to other reports on cisplatin, no significant effects of these novel platinum(IV) complexes were observed on ERK1/2, p38, JNK, Akt and Jaks, suggesting that direct modulation of these signaling proteins may not contribute to the biological effects of CPA-1, CPA-7, and Pt(IV)Cl ${ }_{4}$ $[4,5,6,7]$.

In a previous experiment treatment with cisplatin led to the depletion of essential elements such as $\mathrm{Co}, \mathrm{Cu}, \mathrm{Fe}, \mathrm{Mn}, \mathrm{Mo}, \mathrm{Se}$ and $\mathrm{Zn}$ from the kidney [8] and increased excretion of $\mathrm{Cu}, \mathrm{Mg}$ and $\mathrm{Zn}$ in the urine was observed by Pezonaga and her co-workers [9]. Nevertheless there are no data on the distribution and metabolism of toxic and nonessential elements that can be harmful to health in part by altering signaling pathways. Therefore our aim was to study how treatment with cisplatin changes the concentration of some of these elements in the plasma, liver and kidney of rats.

\section{Materials and methods}




\section{Test material}

Cisplatin (10 mg in $20 \mathrm{~mL}$ ) was obtained from TEVA Pharmaceutical Industries, Petach Tikva, Israel.

\section{Animal experiment}

Twenty male, 8-week-old Wistar rats weighing 175-190 g were randomly divided into 2 groups ( $\mathrm{n}=10$ /group). They were kept individually under standard conventional conditions according to European Council Directive 123. The study conformed to the Declaration of Helsinki guidelines and was approved by the local animal ethical committee.

The control group received $1 \%(\mathrm{w} / \mathrm{v})$ methyl cellulose at $10 \mathrm{~mL} / \mathrm{kg}$ body weight p.o. by gastric gavage twice daily for 14 days. Cisplatin was injected intraperitoneally with a single dose of $6.5 \mathrm{mg} / \mathrm{kg}$ body weight [10]. Cisplatin was suspended in $10 \mathrm{~mL} / \mathrm{kg} 1 \%$ methyl cellulose. For proving the effect of cisplatin to renal dysfunction, blood urea nitrogen (BUN) and creatinin levels were measured on day 12. Rats were terminally anaesthetised with pentobarbitone on day 14 .

\section{Rat samples}

Blood was collected from the thoracic vena cava. Blood was anticoagulated with citrate and centrifuged twice at $2500 \mathrm{rpm}$ for $10 \mathrm{~min}$ at $+4{ }^{\circ} \mathrm{C}$ to obtain plasma.

The kidneys were removed, washed and weighed. The liver was removed, weighed, washed and then homogenized in ice-cold isotonic $\mathrm{KCl}$ solution and the protein concentration was set at $10 \mathrm{~g} / \mathrm{L}$.

\section{Measurement of metal content}

Plasma, liver and kidney samples were weighed (1 g plasma, 3.0-3.5 g liver homogenate and 1 g kidney) into the digestion vessels. Plasma and liver samples were digested with $5 \mathrm{~mL} 65 \%$ nitric acid and $2 \mathrm{~mL}$ hydrogen peroxide, and kidney samples were digested with $10 \mathrm{~mL} 65 \%$ nitric acid and $2 \mathrm{~mL}$ hydrogen peroxide. The digestion was performed in a block digestion system because of the large amount of samples. After digestion and evaporation, the samples were poured into $10 \mathrm{~mL}$ volumetric 
flasks and were filled up to the mark with bidistilled water. Three plasma and liver samples and two kidney samples were prepared from each animal.

Inductively coupled plasma optical emission spectrometric (ICP-OES) method was applied for measuring Al, B, Ba, Cr, Li, Ni, Pb, Pt, Sb, Si, Sn, Sr and V content [11] using a Spectro Genesis ICPOES (Kleve, Germany) equipment. For the standardization of equipment and measurements, Spectro multi-element and Spectrum 3D standards were used. Standards were prepared in the same matrix as the samples. The samples were measured 3 times and blank subtraction was applied. The concentration of V was below detection limit in all samples; therefore this element was omitted from Tables 2, 3 and

4. Furthermore, those metal elements were also omitted from the respective table that were below the detection limit in a certain sample (liver, kidney or plasma) in both groups.

The detection limits for the samples (DL) were calculated from the instrumental detection limit (IDL) of elements, the weights of samples (W) and the final volumes (V) as follows: DL=IDL*V/W. The below detection limit concentrations for some elements are marked by the less-than sign $(<)$ in Tables 2, 3 and 4.

Metal element concentrations in bovine liver solution (High Purity Standards, CRM BL 411213) were measured for the demonstration of reliability and precision of the measurement (Table 1). The recovery (R) was calculated from the declared (DD) and measured values (MD) as follows: $\mathrm{R}=\mathrm{MD} / \mathrm{DD} * 100$. In the case of lead when the concentration was below the instrumental detection limit (IDL $<0.02 \mu \mathrm{g} / \mathrm{mL}$ ) and for those elements (B, Li, Sb, Sn, Sr, Pt), which had no certified data, the repeatability measurements were performed (five times) with standard solutions of $200 \mathrm{ng} / \mathrm{mL}$ and 500 $\mathrm{ng} / \mathrm{mL}$ concentration, and the recovery was calculated from these results (Table 1).

\section{Measurement of redox parameters of the liver}

Total scavenger capacity (induced chemiluminescence assay) was determined with Berthold's Lumat 9501 luminometer on the basis of a method developed by Blázovics and coworkers [12]. Chemiluminescent intensity of the liver homogenate was measured and expressed in relative light unit 
(RLU\%) of the standard light (basic chemical reaction in $\mathrm{H}_{2} \mathrm{O}_{2} / \mathrm{OH}$-microperoxidase-luminol system). The protein content of the liver homogenate was set at $1 \%$ by the Lowry method [13].

The concentration of diene-conjugates was determined in the liver samples according to the description of Ahotupa and coworkers [14].

In the liver homogenate malondialdehyde (MDA) levels were also measured spectrophotometrically by the method of Mansour and coworkers [15]. Trichloroacetic acid solution $(20 \% \mathrm{w} / \mathrm{v}, 2.5 \mathrm{~mL})$ and thiobarbituric acid $(0.67 \% \mathrm{w} / \mathrm{v}, 1 \mathrm{~mL})$ was added to the liver sample $(0.5 \mathrm{~mL})$ and shaken, and then heated for $30 \mathrm{~min}$ at $100{ }^{\circ} \mathrm{C}$. n-Butyl alcohol $(4 \mathrm{~mL})$ was added to the mixture and centrifuged at $3000 \mathrm{rpm}$ for $10 \mathrm{~min}$. The MDA content of n-butyl alcohol solution was calculated from the absorbance read at $535 \mathrm{~nm}$ and it was expressed as $\mathrm{nmol} / \mathrm{g}$.

\section{Statistical calculations}

Means and standard deviations were calculated with MS-Excel, and ANOVA was applied for the determination of significant differences between groups by using GraphPad Prism 5.0 software. The level of significance was set at $\mathrm{p}<0.05$.

\section{Results}

\section{Metal element concentrations in the rat kidney}

Treatment with cisplatin caused a more than 3-fold increase in $\mathrm{Pb}$ concentration in the kidney $(\mathrm{p}<0.05)$ at two weeks after cisplatin administration (Table 2). The concentration of $\mathrm{Pt}$ and $\mathrm{Sb}$ was below the detection limit in the vehicle-treated treated group. On the other hand, a huge increase in the concentrations of these two metal elements was observed in the group treated with cisplatin. The concentrations of other metal elements which could be detected in the kidney (Al, $\mathrm{Ba}, \mathrm{Cr}, \mathrm{Ni}, \mathrm{Pb}, \mathrm{Si}$, $\mathrm{Sn}, \mathrm{Sr}$ ) did not change at two weeks after treatment with cisplatin.

\section{Metal element concentrations in the rat plasma}


Treatment with cisplatin increased the concentrations of several metal elements in the plasma (Al, $\mathrm{B}, \mathrm{Ba}, \mathrm{Cr}, \mathrm{Ni}, \mathrm{Pb}, \mathrm{Sb}$ and $\mathrm{Sr}$ ) in comparison to the group treated with vehicle (Table 3). Especially huge increases in the plasma concentrations of $\mathrm{B}, \mathrm{Pb}$ and $\mathrm{Sb}$ were found in the group treated with cisplatin, as the concentrations of these metal elements were below the limit of detection in the vehicle-treated group, but were at least 13 to 300 -fold higher at two weeks after treatment with cisplatin.

\section{The effects of cisplatin on the rat liver}

The concentration of Pt was below the limit of detection in the group treated with vehicle, while Pt concentration was detectable in the group treated with cisplatin. However, Pt concentration was much lower in the liver than in the kidney on day 14 after administration of the platinum complex (Table 4).

The total scavenger capacity in the liver of the cisplatin-treated rats decreased as the amount of $\cdot \mathrm{OH} / \mathrm{H} 2 \mathrm{O} 2$ radicals in the $\mathrm{H} 2 \mathrm{O} 2 / \cdot \mathrm{OH}$ - microperoxidase-luminol-system was considerably higher in the liver of rats treated with cisplatin than in the liver of rats treated with vehicle (Fig. 1).

The diene conjugate level in the liver decreased in the cisplatin-treated group (Fig. 2). Cisplatin increased the oxidation of lipids in the liver proved by the elevated malondialdehyde concentration in the liver homogenate (Fig. 3).

\section{Discussion}

In the liver Pt was detected in a small amount (Table 4) compared to that in the kidney. However, after treatment with a different platinum(IV) complex, LA-12, Sova and co-workers [16] published higher Pt accumulation in the liver. These contrary results suggest that the accumulation of Pt in the liver depends on the organic compounds used for complexation of Pt. In our study treatment with cisplatin at the dose applied did not affect other toxic and non essential element concentrations in the liver at two weeks after cisplatin administration. 
It has already been shown that cisplatin was significantly metabolized in the liver [17] and the metabolites were excreted by the kidney [2]. The liver damaging effect of toxic metal ions is hardly known. Toxic heavy metals are able to occupy the sites of essential elements and can cause toxicity through oxidative mechanisms [18]. We measured the total scavenger capacity of the liver because of the free radical generating ability of toxic elements, and the concentration of Pt increased in the liver of cisplatin-treated rats. The amount of $\bullet \mathrm{OH} / \mathrm{H}_{2} \mathrm{O}_{2}$ radicals in the $\mathrm{H}_{2} \mathrm{O}_{2} / \bullet \mathrm{OH}-$ microperoxidase-luminolsystem were increased. This observation means a decrease in radical scavenging capacity of the liver similarly to that found in the plasma of cisplatin-treated rats in earlier experiments [8]. In line with the above finding the diene conjugate level decreased and the malondialdehyde concentration was elevated in the liver of the cisplatin-treated group. The mechanism of these changes was not addressed in this study but published results suggest that cisplatin can generate reactive oxygen and nitrogen species by increasing the activity of the cytochrome P450 system, NADPH oxidases, xanthine oxidase and adenosine deaminase. Cisplatin can also deplete glutathione and inhibit the activity of antioxidant enzymes $[19,20]$. Nevertheless prooxidant and toxic effects of other metals should also be taken into account. These results collectively suggest that despite a small increase in the Pt concentration due to treatment with cisplatin the redox status and protection against oxidative stress was impaired in the liver.

On the other hand, the kidney, the main organ of Pt-accumulation, contained a relevant amount of Pt (Table 2). Sabolic and co-authors [21] obtained similar results for Pt in the kidney after treatment of rats with cisplatin $(5 \mathrm{mg} / \mathrm{kg}$ i.p.), however changes in other metal element concentrations were not studied by them. Cisplatin can damage organs, tissues and cells and the most serious toxic effect appears in the kidney, where $\mathrm{Pt}$ is accumulated [21, 22]. In our study, the concentration of $\mathrm{Pb}$ and $\mathrm{Sb}$ also increased in the kidney, while the concentration of other metal elements did not change.

It is well-known that cisplatin administration resulted in serious histopathological changes and renal dysfunction that was related to the increase of renal vascular resistance and injury of proximal 
tubular cells $[23,24]$. One of the main elimination pathways of toxic metals is excretion by the urine. Therefore, renal dysfunction can interfere with the ability to get rid of toxic metals in the body from the one hand, and can impair tubular reabsorption leading to depletion of some essential metal elements on the other hand. In fact, treatment with cisplatin decreased the levels of $\mathrm{Cu}, \mathrm{Mg}$ and $\mathrm{Zn}$ in the plasma and led to the depletion of $\mathrm{Cu}, \mathrm{Mg}$ and $\mathrm{Zn}$ essential elements by the urine in a human study [9]. Furthermore, in the rat kidney decreases in the concentration of some essential elements such as Co, $\mathrm{Cu}, \mathrm{Fe}, \mathrm{Mn}, \mathrm{Mo}, \mathrm{Se}$ and $\mathrm{Zn}$ was proved by us [8].

As a consequence of decreased elimination of heavy metals the concentration of several toxic and non-essential elements increased in the plasma. In line with the high accumulation of $\mathrm{Pb}$ and $\mathrm{Sb}$ in the kidney their concentration was also markedly elevated in the plasma, but the levels of $\mathrm{Al}, \mathrm{B}, \mathrm{Ba}, \mathrm{Cr}$, $\mathrm{Ni}$, and $\mathrm{Sr}$ were also increased. Metal elements bind mainly to plasma proteins. In the blood Al binds mainly to transferrin at the vacant sites of iron and to albumin in a smaller degree [25]. Chromium has similar properties to $\mathrm{Al}$ [26]. The main Ni-binding protein is also albumin, although $\alpha$-macroglobulin and histidine can also react with this element in the plasma [27].

Cisplatin circulates in the blood bound to high molecular weight proteins and low molecular weight other compounds, as well as in the form of cisplatin aqua complexes [25]. Cisplatin is transformed to different metabolites in the organism. About fifty percent of cisplatin remained unchanged for more than one hour after treatment but cisplatin was fully transformed to some kind of metabolite within 24 hours [28]. The Pt-containing species disappear from the blood relatively rapidly. This may be a likely explanation for the observation that Pt was not detected in the plasma.

According to the results of our study cisplatin accumulates in the liver to small extent. Despite a small increase in Pt concentration in the liver, the redox status and protection against oxidative stress was impaired in the liver. Cisplatin alters the metabolism of toxic and non-essential elements for a long period after treatment. As a result some metal elements accumulate in the kidney, but most toxic metals circulate in the blood at increased concentrations. 


\section{Acknowledgement}

This work was supported by Ivy Medical Chemicals Plc (54 Sun Street, Waltham Abbey, Essex EN9 1EJ, UK). There is no conflict of interest.

\section{References}

[1] Bose RN. Biomolecular targets for platinum antitumor drugs. Mini Rev. Med. Chem. 2002; 2: 103111.

[2] Liao Y, Lu X, Lu C, Li G, Jin Y, Tang H. Selection of agents for prevention of cisplatin-induced hepatotoxicity. Pharmacol. Res. 2008; 57: 125-31.

[3] Persons DL, Yazlovitskaya EM, Cui W, Pelling JC. Cisplatin-induced activation of mitogenactivated protein kinases in ovarian carcinoma cells inhibition of extracellular signal-regulated kinase activity increases sensitivity to cisplatin. Clin. Cancer Res. 1999; 5: 1007-14.

[4] Turkson J, Zhang S, Palmer J, Kay H, Stanko J, Mora LB, Sebti S, Yu H, Jove R. Inhibition of constitutive signal transducer and activator of transcription 3 activation by novel platinum complexes with potent antitumor activity. Mol. Cancer Ther. 2004; 3: 1533-42.

[5] Mansouri A, Ridgeway LD, Korapati AL, Zhang QX, Tian L, Wang YB, Siddik ZH, Mills GB, Claret F X. Sustained activation of JNK/p38 MAPK pathways in response to cisplatin leads to Fas ligand induction and cell death in ovarian carcinoma cells. J. Biol. Chem. 2003; 278: 19245-56.

[6] Song H, Sondak VK, Barber DL, Reid TJ, Lin J. Modulation of Janus kinase 2 by cisplatin in cancer cells. Int. J. Oncol. 2004; 24: 1017-26.

[7] Ott I, Gust R. Non platinum metal complexes as anti-cancer Drugs Archiv der Pharmazie 2007; 340: $117-26$.

[8] Máthé C, Szénási G, Sebestény A, Blázovics A, Szentmihályi K, Hamar P, Albert M. Protective effect of CV247 against cisplatin nephrotoxicity in rats. Human Exp. Toxicol. 2013; Advance Access published May 7, 2013. doi: 10.1177/0960327113480972. 
[9] Pezonaga I, Taylor A, Dobrota M. The effects of platinum chemotherapy on essential trace elements. Eur. J. Cancer Care 1996; 5: 122-6.

[10] Ognjanovic BI, Djordjevic NZ, Matic MM, Obradovic JM, Mladenovic JM, Stajn AS, Saicic ZS.. Lipid peroxidative damage on Cisplatin exposure and alterations in antioxidant defense system in rat kidneys: a possible protective effect of selenium. Int. J. Mol. Sc i. 2012;13: 1790-1803.

[11] Szentmihályi K, Fehér E, Vinkler P, Kéry Á, Blázovics A. Metabolic alterations of toxic and nonessential elements by the treatment of Sempervivum tectorum extract in a hyperlipidemic rat model. Toxicol. Pathol. 2004; 32: 50-7.

[12] Blázovics A, Kovács Á, Lugasi A, Hagymási K, Bíró L, Fehér, J. Antioxidant defence in erythrocytes and plasma of patients with active and quiescent Crohn's disease and ulcerative colitis: A chemiluminescent study. Clin. Chem. 199; 45: 895-6.

[13] Lowry OH, Rosebrough NJ, Farr AL, Randall AJ. Protein measurement with the Folin phenol reagent. J. Biol. Chem. 1951; 193: 265-74.

[14] Ahotupa M, Marniemi J, Lehtimäki T, Talvinen K, Raitakari OT, Vasankari T, Viikari J, Luoma J, Yla-Herttuala S. Baseline diene conjugation in LDL lipids as a direct measure of in vivo LDL oxidation. Clin. Biochem. 1998; 31: 257-261.

[15] Mansour HH, Hafez HF, Fahmy NM. Silymarin modulates cisplatin-induced oxidative stress and hepatotoxicity in rats. J. Biochem. Mol. Biol. 2006; 39: 656-61.

[16] Sova P, Chladek J, Zak F, Mistr A, Kroutil A, Semerad M, Slovak Z. Pharmacokinetics and tissue distribution of platinum in rats following single and multiple oral doses of LA-12 [(OC-6-43)bis(acetato)(1-adamantylamine) amminedichloroplatinum(IV)]. Int. J. Pharm. 2005; 288: 123-9

[17] Naziroglu M, Karaoğlu A, Aksoy AO. Selenium and high dose vitamin E administration protects cisplatin-induced oxidative damage to renal liver and lens tissues in rats. Toxicology 2004; 195 : 221-30. 
[18] Stohs SJ, Bagchim MD. Oxidative mechanisms in the toxicity of metal ions. Free Rad. Biol. Med. 1995; 18: 321-36.

[19] Yilmaz HR, Sogut S, Ozyurt B, Ozugurlu F, Sahin S, Isik B, Uz E, Ozyurt H. The activities of liver adenosine deaminase, xanthine oxidase, catalase, superoxide dismutase enzymes and the levels of malondialdehyde and nitric oxide after cisplatin toxicity in rats: protective effect of caffeic acid phenethyl ester. Toxicol. Ind. Health 2005; 3-4: 67-73.

[20] Koc A, Duru M, Ciralik H, Akcan R, Sogut S. Protective agent, erdosteine, against cisplatin-induced hepatic oxidant injury in rats. Mol. Cell Biochem. 2005; 278: 79-84.

[21] Sabolic I, Breljak D, Herak-Kramberger CM, Ljubojevic M. Expression of multidrug resistance Pglycoprotein Mdr1 (Abcb1) in rat kidney proximal tubules is up-regulated by nephrotoxic metals. Metal Ions Biol. Med. 2008; 10: 315-21.

[22] Kim JS, Lee JM, Chwae YJ, Kim YH, Lee JH, Kim KH, Lee TH, Kim SJ, Park JH. Cisplatin induced apoptosis in Hep3B cells: mitochondriaa-dependent and -independent pathways. Biochem Pharmacol. 2004; 67: 1459-68.

[23] Do Amaral CL, Francescato HD, Coimbra TM, Costa RS, Darin JDC, Antunes LMG, Bianchi MD P. Resveratrol attenuates cisplatin-induced nephrotoxicity in rats. Arch. Toxicol. 2008; 82: 363-70.

[24] Atessahin A, Yilmaz S, Karahan I, Ceribasi AO, Karaoglu A. Effects of lycopene against cisplatin-induced nephrotoxicity and oxidative stres in rats. Toxicology 2005; 212:116-23.

[25] Daydé S, Champmartin D, Rubini P, Berthon G. Aluminium speciation studies in biological fluids. Part 8. A quantitative investigation of $\mathrm{Al}(\mathrm{III})$-amino acid complex equilibria and assessment of their potential implications for aluminium metabolism and toxicity. Inorg. Chim. Acta 2002, 339: 513-24.

[26] Ducros V. Chromium metabolism. Biol. Trace Elem. Res. 1992; 32: 65-77.

[27] Sunderman FW. Biological monitoring of nickel in humans. Scand. J. Work Env. Health. 1993; 19: 34-8. 
[28] Daley-Yates PT, Mc Brien DCH. Cisplatin metabolites in plasma, a study of their pharmacokinetics and importance in the nephrotoxic and antitumour activity of cisplatin. Biochem. Pharmacol. 1984; 33: 3063-70. 
Table 1. Results of element concentration (mean $\pm \mathrm{SD}, \mathrm{ng} / \mathrm{mL}$ ) in reference solution (Bovine liver solution, High Purity Standards, CRM BL 411213) standards and they recovery data

\begin{tabular}{|c|c|c|c|c|}
\hline Elements & $\begin{array}{l}\text { Declared } \\
\text { concentration in } \\
\text { reference solution }\end{array}$ & $\begin{array}{c}\text { Standard } \\
\text { concentration }\end{array}$ & $\begin{array}{l}\text { Measured } \\
\qquad(n=5)\end{array}$ & $\begin{array}{c}\text { Recovery } \\
(\%)\end{array}$ \\
\hline $\mathrm{Al}$ & 200 & & $199 \pm 2$ & 99.5 \\
\hline B & & 200 & $188 \pm 9$ & 94.0 \\
\hline $\mathrm{Ba}$ & 10 & & $10.5 \pm 0.5$ & 100.5 \\
\hline $\mathrm{Cr}$ & 1 & & $1.06 \pm 0.05$ & 106.0 \\
\hline $\mathrm{Li}$ & & 200 & $199 \pm 6$ & 99.5 \\
\hline $\mathrm{Ni}$ & 2 & & $1.94 \pm 0.05$ & 97.0 \\
\hline $\mathrm{Pb}$ & 2 & 200 & $202 \pm 16$ & 101.0 \\
\hline $\mathrm{Pt}$ & & 500 & $502 \pm 2$ & 100.4 \\
\hline $\mathrm{Sb}$ & & 200 & $186 \pm 7$ & 93.5 \\
\hline $\mathrm{Si}$ & 200 & & $199 \pm 2$ & 99.5 \\
\hline $\mathrm{Sn}$ & & 200 & $203 \pm 17$ & 101.5 \\
\hline $\mathrm{Sr}$ & & 200 & $202 \pm 9$ & 101.0 \\
\hline V & & 200 & $199 \pm 100$ & 99.5 \\
\hline
\end{tabular}


Table 2. Metal element concentrations $(\mu \mathrm{g} / \mathrm{g} \pm \mathrm{SD})$ in the rat kidney in the groups treated with vehicle and cisplatin (single dose of $6.5 \mathrm{mg} / \mathrm{kg}$ body weight) at 2 weeks after cisplatin administration.

\begin{tabular}{lccc}
\hline Elements & Vehicle $(n=10)$ & Cisplatin $(n=10)$ & $\mathrm{p}$ value \\
\hline $\mathrm{Al}$ & $5.66 \pm 1.32$ & $6.58 \pm 2.60$ & $>0.05$ \\
$\mathrm{Ba}$ & $0.092 \pm 0.042$ & $0.083 \pm 0.058$ & $>0.05$ \\
$\mathrm{Cr}$ & $0.135 \pm 0.027$ & $0.149 \pm 0.021$ & $>0.05$ \\
$\mathrm{Ni}$ & $0.154 \pm 0.061$ & $0.135 \pm 0.050$ & $>0.05$ \\
$\mathrm{~Pb}$ & $1.29 \pm 0.73$ & $4.36 \pm 3.50$ & $<\mathbf{0 . 0 5}$ \\
$\mathrm{Pt}$ & $<0.035$ & $3.30 \pm 0.32$ & $<\mathbf{0 . 0 5}$ \\
$\mathrm{Sb}$ & $<0.02$ & $0.739 \pm 0.137$ & $<\mathbf{0 . 0 5}$ \\
$\mathrm{Si}$ & $34.78 \pm 8.05$ & $38.94 \pm 5.91$ & $>0.05$ \\
$\mathrm{Sn}$ & $0.570 \pm 0.290$ & $1.303 \pm 1.076$ & $>0.05$ \\
$\mathrm{Sr}$ & $0.115 \pm 0.116$ & $0.064 \pm 0.017$ & $>0.05$ \\
\hline
\end{tabular}


Table 3. Metal element concentrations $(\mu \mathrm{g} / \mathrm{g} \pm \mathrm{SD})$ in the rat plasma in the groups treated with vehicle and cisplatin (single dose of $6.5 \mathrm{mg} / \mathrm{kg}$ body weight) at 2 weeks after cisplatin administration.

\begin{tabular}{llll}
\hline Elements & Vehicle $(\mathrm{n}=10)$ & Cisplatin $(\mathrm{n}=10)$ & $\mathrm{p}$ value \\
\hline $\mathrm{Al}$ & $1.01 \pm 0.29$ & $3.11 \pm 2.79$ & $<\mathbf{0 . 0 5}$ \\
$\mathrm{B}$ & $<0.05$ & $15.05 \pm 13.96$ & $<\mathbf{0 . 0 5}$ \\
$\mathrm{Ba}$ & $0.089 \pm 0.042$ & $0.183 \pm 0.128$ & $<\mathbf{0 . 0 5}$ \\
$\mathrm{Cr}$ & $0.029 \pm 0.013$ & $0.068 \pm 0.056$ & $<\mathbf{0 . 0 5}$ \\
$\mathrm{Ni}$ & $0.057 \pm 0.027$ & $0.124 \pm 0.074$ & $<\mathbf{0 . 0 5}$ \\
$\mathrm{Pb}$ & $<0.2$ & $2.58 \pm 1.58$ & $<\mathbf{0 . 0 5}$ \\
$\mathrm{Sb}$ & $<0.02$ & 1.82 & $<\mathbf{0 . 0 5}$ \\
$\mathrm{Si}$ & $9.31 \pm 2.66$ & $17.45 \pm 12.31$ & $>0.05$ \\
$\mathrm{Sn}$ & $0.313 \pm 0.098$ & $0.403 \pm 0.198$ & $>0.05$ \\
$\mathrm{Sr}$ & $0.066 \pm 0.027$ & $0.107 \pm 0.074$ & $<\mathbf{0 . 0 5}$ \\
\hline
\end{tabular}


Table 4. Metal element concentrations $(\mu \mathrm{g} / \mathrm{g} \pm \mathrm{SD})$ in the rat liver of vehicle and cisplatin-treated rats (single dose of $6.5 \mathrm{mg} / \mathrm{kg}$ body weight) at two weeks after cisplatin administration.

\begin{tabular}{lccc}
\hline Elements & Vehicle $(\mathrm{n}=10)$ & Cisplatin $(\mathrm{n}=10)$ & $\mathrm{p}$ value \\
\hline $\mathrm{Al}$ & $0.501 \pm 0.169$ & $0.572 \pm 0.369$ & $>0.05$ \\
$\mathrm{~B}$ & $0.960 \pm 0.730$ & $2.08 \pm 2.42$ & $>0.05$ \\
$\mathrm{Ba}$ & $0.058 \pm 0.107$ & $0.223 \pm 0.593$ & $>0.05$ \\
$\mathrm{Cr}$ & $0.013 \pm 0.003$ & $0.014 \pm 0.006$ & $>0.05$ \\
$\mathrm{Ni}$ & $0.037 \pm 0.042$ & $0.045 \pm 0.060$ & $>0.05$ \\
$\mathrm{~Pb}$ & $0.152 \pm 0.079$ & $0.118 \pm 0.130$ & $>0.05$ \\
$\mathrm{Pt}$ & $<0.010$ & $0.021 \pm 0.002$ & $<\mathbf{0 . 0 5}$ \\
$\mathrm{Sb}$ & $0.147 \pm 0.060$ & $0.120 \pm 0.050$ & $>0.05$ \\
$\mathrm{Si}$ & $6.04 \pm 3.30$ & $4.74 \pm 2.29$ & $>0.05$ \\
$\mathrm{Sn}$ & $0.061 \pm 0.046$ & $0.030 \pm 0.012$ & $>0.05$ \\
$\mathrm{Sr}$ & $0.041 \pm 0.019$ & $0.048 \pm 0.020$ & $>0.05$ \\
\hline
\end{tabular}




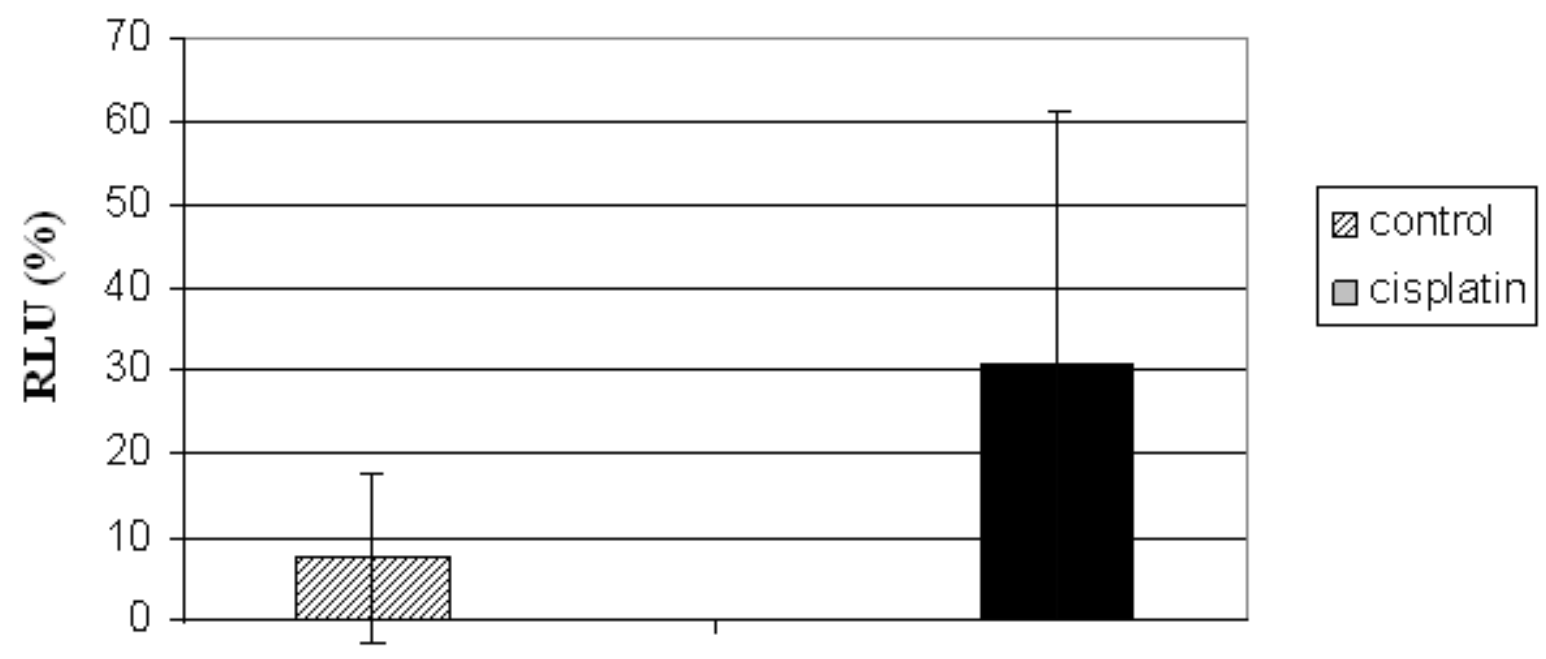

Figure .1. Total scavenger capacity expressed as Chemiluminescence chemiluminescence intensity $(\mathrm{RLU} \% \pm \mathrm{SD}$ ) in the liver of control- and cisplatin cisplatin-treated rats (single dose of $6.5 \mathrm{mg} / \mathrm{kg}$ body weight) measured the in $\mathrm{H}_{2} \mathrm{O}_{2} /^{\circ} \mathrm{OH}$-microperoxidase-luminol-system.

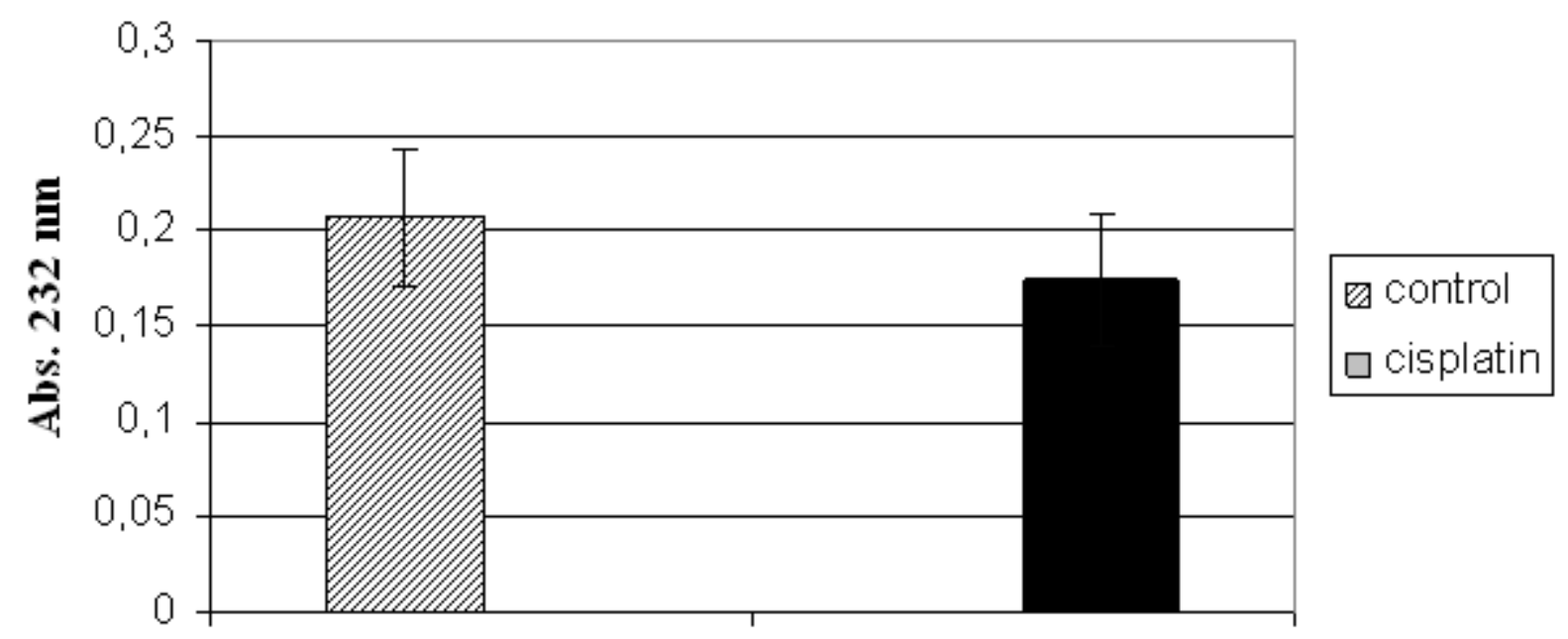

Fig. 2. Diene conjugate content (absorbance $\pm \mathrm{SD}$, measured at $232 \mathrm{~nm}$ ) in the liver of control and cisplatin cisplatin-treated rats (single dose of $6.5 \mathrm{mg} / \mathrm{kg}$ body weight) 


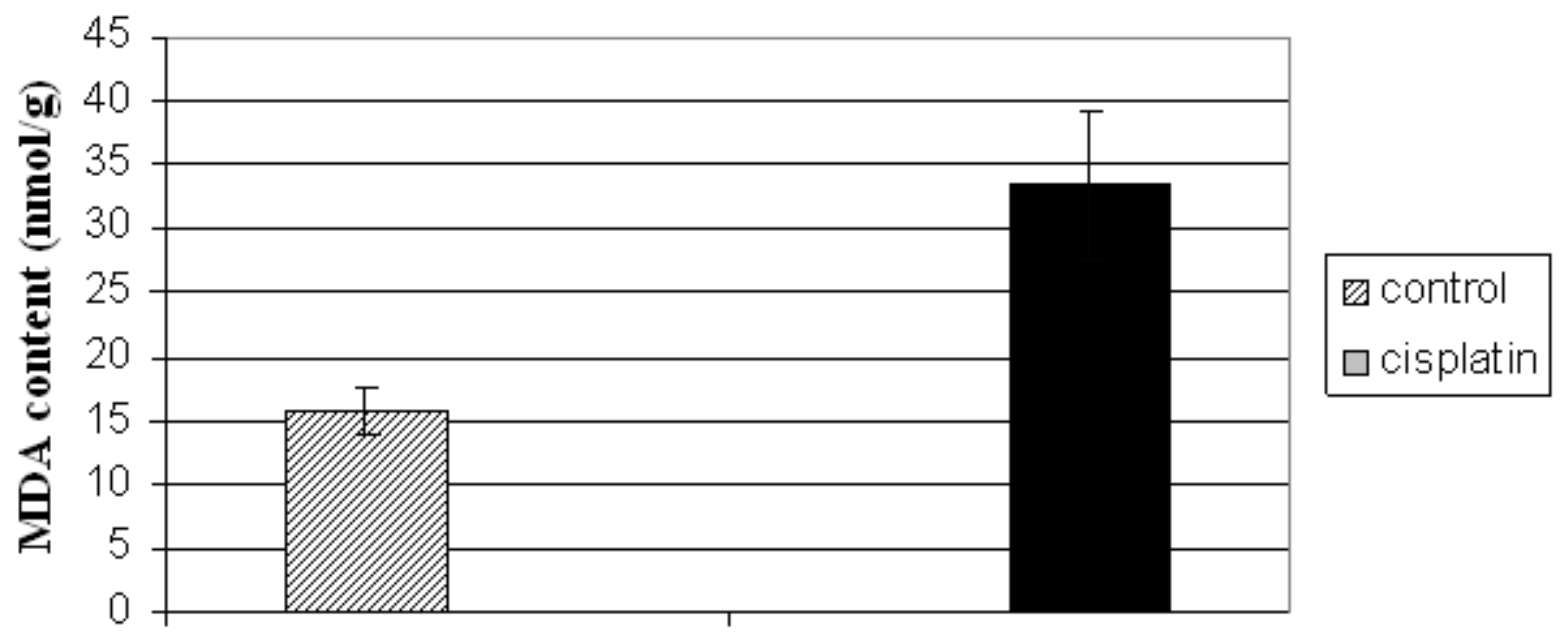

Fig.ure 3. Malondyaldehyde levels ( $\mathrm{nmol} / \mathrm{g} \pm \mathrm{SD}$, measured at $535 \mathrm{~nm}$ ) in the liver of control vehicleand cisplatin cisplatin-treated rats (single dose of $6.5 \mathrm{mg} / \mathrm{kg}$ body weight) 